\title{
PALABRAS DEL DR. JUAN CHÁVEZ MOLINA CON MOTIVO DE SU RECONOCIMIENTO COMO PROFESOR HONORARIO DE LA UNIFE
}

A continuación, la Facultad de Derecho de la UNIFE, desea rendir un homenaje a quien fuera nuestro docente y amigo Dr. Juan Chávez Molina. Reproducimos el discurso que brindó el día de su incorporación, 11 de noviembre del 2010, como Profesor Extraordinario en calidad de Honorario de la Universidad Femenina del Sagrado Corazón (UNIFÉ):

"Hermana Rectora de la Unifé; Decano de la Facultad de Derecho; Doctora Sylvia y autoridades que nos presiden en esta mesa; amigos, una sola palabra para llamarlos a todos ustedes, amigos fraternos:

Qué trances en los que los hombres nos vemos. Alegría por un lado y duda por otro, para estar seguro que las palabras que quisieran traducir con vocablos estén a la altura del sentimiento que nace del corazón, golpea en las sienes y se atropella en el cerebro para decir una y otra y otra vivencia, en todo lo material pero, más que en eso, en todo lo espiritual que significa para quienes hemos laborado acá.

$Y$ veo el rostro de cuántos colegas que me acompañaron en el honroso y difícil trance de formar a las alumnas de Derecho. Quizás -y no es en contra del machismo- con más alcance, por ser el origen de la vida, pues las mujeres tienen ese don divino. Mientras nosotros pasamos muy rápido por la paternidad, ellas llevan nueve meses de dar vida y el sustento. Y lo que los pueblos son, en realidad son más por las madres que criaron hijos valerosos, honrados, decentes, amantes de la justicia, camino de la libertad que es la base sólida de la paz social. A ellas, debemos muchos destinos sagrados.

Pues bien, como decía, es fácil abrir el corazón de uno y decirles a ustedes cuanto quisiera mi alma expresarles, pero a la vez parecería contradictorio qué difícil que esos verbos digan el alcance de nuestro amor fraterno y amor de amistad, que es quizás muchas veces más grande que el amor consanguíneo.

Vemos -y los abogados somos testigos presenciales de esoque hay hermanos que luchan como tremendos enemigos; pero cuando uno tiene un amigo, realmente amigo, esos sentimientos de fraternidad nunca se están en contra, siempre se unen para sacar adelante los grandes valores.

Cuánto quisiera decir, cuanto se agolpa al diapasón de mi corazón que martillea mis sentidos, en las sienes y en el cerebro; no saben cual palabra escoger, ni cual decir para ser lo mejor. Pero tengan seguro que llevo esta medalla que me impone la Universidad, como lo mejor que puedo ostentar en el pecho; el verde: la esperanza y el blanco: la pureza, valores en sí mismos eternos.

$Y$ esto me trae cuántos recuerdos de acá, que me emocionan, me hacen respirar.

Recuerdo que cuando se me propuso para ser profesor, de ustedes alumnas, que llevo en el corazón, yo dije: Estoy acostumbrado a enseñar, más o menos bien o mal, pero a aulas en donde conviven y transmiten sus deseos, sus inquietudes, hombres y mujeres, pero nunca he enseñado en un salón de solo elementos femeninos; "eso debe ser muy grave", pensaba. Además de la belleza que cada cual tiene, es, como repito, el valor divino de crear la vida que solo ustedes mujeres pueden ostentar.

Pues bien, en esta Lima virreinal, gris de continuo, abriendo el sol desde hace pocos días, desde que recibí la noticia de que me daban esta condecoración, yo dije: "el cielo se pone contento y alumbra con la luz divina".

Sé que mis años, no son que pueda barruntar muchos más de vida; son menos años de vida, indudablemente, pero ellos serán de lucha, porque mi alma arequipeña, y sobre eso peruana, me dio un valor al cuadrado para defender la libertad de la Patria; hemos cantado el Himno Nacional sin la estrofa apócrifa que tantos años nos hizo decir 
inmerecidamente "Largo tiempo en silencio gimió...”, y no eran gemidos los que debíamos haber dicho; felizmente hemos cantado ahora otra de las estrofas.

Pues bien, hemos conversado un poco, yo me voy muy alegre, muy orgulloso, pero con un orgullo sano, que no es ni vanidad ni sentimiento malsano: un orgullo de progreso, de pureza, de desear ser cada vez mejor, para que cuando lleguemos a dar la justicia, que ya se nos aproxima, ante la luz divina, podamos mostrar algunos méritos entre sus efectos.

Volteo a la derecha y veo a Sylvia; me acuerdo de su padre y qué luchas las que tuvo y como se esforzó para crear, por ejemplo, los decretos de urgencia, que había un sector del Parlamento que pensaban que eran ilegales e inconstitucionales y querían sancionar. Y me tocó la suerte -valga como anécdota-, de estar en el ejercicio ad interim del Decanato, porque el Decano había ido a Europa en representación de su función y el Parlamento preguntó cuál era la opinión del Colegio de Abogados de Lima; y entonces, ausente el Decano titular, como Decano a.i., tuve que dar y decir que hay un error en el Parlamento: los decretos de urgencia requieren tales y cuales requisitos en los países donde funcionan y tienen que darse cuenta al Par- lamento que es libérrimo para que, si el Ministro se ha equivocado, derogar, modificar o responsabilizar; y, de esta manera, la tacha que el Parlamento proponía, cayó ante los argumentos de ese dictamen del Colegio de Abogados de Lima, que tuve el honor de firmar. Qué brillante carrera hizo, en todo sentido, llegó al Ministerio, y cuánto bien hizo.

Bien, hermanos; bien, amigos, fraterno saludo a todos ustedes y mil gracias Reverenda Madre, por este honor que llevaré como gloria para mis hijos, y para que mis descendientes sepan que hay un verde esperanza y un blanco puro y nítido que nunca deben manchar." 